\title{
LANDFORMS AND GEOMORPHOSITES ONGOING CHANGES: CONCEPTS AND IMPLICATIONS FOR GEOHERITAGE PROMOTION
}

\author{
Manuela Pelfini, Irene Bollati \\ Earth Sciences Department “Ardito Desio", Università degli Studi di Milano, Milan, Italy
}

Manuscript received: January 23, 2014

Revised version: February 13, 2014

Pelfin M., Bollati I., 2014. Landforms and geomorphosites ongoing changes: Concepts and implications for geoheritage promotion. Quaestiones Geographicae 33(1), Bogucki Wydawnictwo Naukowe, Poznań, pp. 131-143, 3 figs, 1 table. DOI 10.2478/quageo-2014-0009, ISSN 0137-477X

\begin{abstract}
The promotion of geological and geomorphological heritage is growing in importance for educational initiatives. The constantly increasing interest towards changing landforms due to changing climate conditions asks not only for improving the values of the cultural proposals but also for précising the subject of the discussion. Cultural trails and natural resources valorisation are more and more frequently based on the concept of geomorphosite, which is strictly linked to landform typology definitions. In sensitive areas, changing geomorphosites are considered of great interest as a typical response to changes in climate. In this paper, on the basis of recent research, we discuss the definitions of landforms and geomorphosites activity in relation to surface processes dynamics. In addition, we discuss the implications of geomorphological surface processes for geomorphosite evolution and degradation and their consequent impact on related valorisation activities. We indicate how both active and passive landforms, and therefore geomorphosites, are of great interest for scientific, educational and tourism purposes.
\end{abstract}

KEY WORDS: active geomorphosites, landforms activity, geoheritage, tourism

Address of the corresponding author: Manuela Pelfini, Earth Sciences Department "Ardito Desio", Università degli Studi di Milano, Via Mangiagalli, 34, 20133 Milan, Italy, e-mail: manuela.pelfini@unimi.it

\section{Introduction and aims}

The promotion of geological and geomorphological heritage is growing in importance for cultural tourism, landscape valorisation and educational initiatives as thematic paths and itineraries (e.g., Panizza, Piacente 2003, Reynard 2009, Garavaglia, Pelfini 2011, Bollati et al. 2013). Cultural trails and natural resources valorisation are increasingly based on the concept of geomorphosite (i.e., site of geomorphological interest; see Panizza 2001). Based on this concept, evaluations of geomorphosites are conducted using different approaches and a quantification of various attrib- utes, depending on the adopted methodology (the most recent state of art has been outlined by Reynard, Coratza 2013).

Landforms and landscapes represent the starting point for defining simple or complex geomorphosites according to commonly accepted definitions (e.g., Panizza 2001, Reynard, Panizza 2005). Many geomorphosites are characterised by a high cultural value, due to their connection with human activities and settlements (Panizza, Piacente 2003, Reynard et al. 2007), as well as by their geohistorical importance (i.e., Bollati et al. 2012a).

There has been much discussion about the definition of geomorphosites. A generally accept- 
ed definition was proposed by Panizza (2001): a geomorphosite is a landform to which a value can be attributed and becomes a geomorphological resource if usable by the society". Furthermore, a twofold approach is considered in relation to the purpose of the research (Reynard 2009): i) a restrictive definition considers geomorphosites as witnesses of the Earth history (see Grandgirard 1999); and ii) a broader definition considers geomorphosites as all of the landforms to which a value can be given in term of cultural, aesthetic and economic attributes (see Panizza, Piacente 2003).

Geomorphosites play an important role in landscape valorisation, especially in sensitive areas, where, for example, changes in climate induce variations in the intensity and frequency of surface processes and, as a consequence, major changes in the landscape.

Active geomorphosites, which allow the visualization of geo(morpho)logical processes in action"(Reynard 2004a), are considered of great interest for their possible evolution as a consequence of climate change (e.g., for glaciers Diolaiuti, Smiraglia 2010, Gavrilâ, Anghel 2013) or tourist pressure (Reynard 2004b, Reynard, Panizza 2005) as well as for possible educational applications (Hooke 1994, Reynard 2004b, Bollati et al. 2011). The recently developing interest in active geomorphosites covers different topics in the frame of geomorphosites: evaluation, valorisation, protection and impact and risk analysis related to geomorphosites selection and fruition.

Even if there is agreement within the scientific community about classification and definitions of active processes acting on both landforms and geomorphosites, there is still confusion in the common use of terms.

In most peoples' opinion, landforms, that are rapidly changing in their shape, are often considered active and independent of the type of process shaping the single landforms.

Therefore, the aim of this paper is to provide a contribution to the question When can a geomorphosites be considered active? Furthermore, this paper focuses on the following: i) outlining geomorphosite activity referring to landform activity; ii) analysing recent research conducted on active geomorphosite evolution in different morphoclimatic environments, in order to better address future efforts regarding this topic; and iii) individuating implications of geomorphological dynamics in geomorphosite evolution and its relative impact on tourism and cultural valorisation proposals.

\section{Definitions: the scientific discussion}

The valorisation of geomorphological heritage should be based on landforms and geomorphosites activity and evolution rates. Geomorphosites can be representative of landscape evolution in response to climate change (e.g., Strasser et al. 1995, Reynard 2004a, Garavaglia et al. 2010) or human activities (i.e., Panizza, Piacente 2003). Geomorphosites global value (see Reynard et al. 2007 and Bollati et al. 2012a) is calculated according to the value of a single landform or of the complex/composed landforms they are representative of. Moreover, active processes are considered of great interest, as they can rapidly induce geomorphosite degradation or changes or may affect tourists' fruition in term of hazard and risk (e.g., Pelfini et al. 2009, Smith et al. 2009, Bollati et al. 2013). It may be helpful to clarify the concepts and relations existing between landforms activity and geomorphosites in order to translate them for dissemination purposes.

\section{Landforms activity}

Landscape, as defined by Slaymaker et al. (2011), may be considered an intermediate scale region, comprising landforms and landforms assemblages, ecosystems and anthropogenically modified land and it is in constant change (Giardino et al. 2010) and landforms are the results of the interaction of weathering, surface modelling processes, soils, biotic environment actions linked with structural control and tectonic activity. In this framework human disturbance has to be considered too (Brierley et al. 2013). Thus, landforms result from constructive and destructive processes working on structures (Tricart 1965, Bloom 1991, Summerfield 1991). According to Bloom (1991), landscapes are surfaces composed of an assemblage of subjectively defined, irregular, lesser surfaces and each element of the landscape that can be observed in its entirety and has consistence of form or regular change of form may be considered a landform. 
The activity of a landform depends on two main elements: the morphoclimatic system, which drives exogenous processes in particular, and the tectonic context and structural features in general, which result from endogenous processes (e.g. Ilies, Josan 2008). Climate is one of the major controlling factors in landscape modelling, as many morphogenetic processes may change in frequency and intensity in relation with climate changes. This degree of activity of landforms is related to the morphoclimatic system in which landforms are inserted (e.g. Gavrilâ, Anghel 2013).

In this framework, there are numerous speculations about the concept of activity in geomorphology since it is a relevant issue for mapping and hazards analysis (Bisci, Dramis 1991). In general, present landscapes are always a combination of inherited and active landforms (Bosson, Reynard 2011).

Bisci and Dramis (1991) define active landforms as those evolving under the action of the processes that generated them and thus are still evolving. When landforms are not currently active, in equilibrium in the present morphoclimatic system and they can be reactivated, they may be considered quiescent. Moreover these authors assert that the return time of processes has to be greater than one year to define a landform as quiescent; if shorter, the landform may be considered active and characterised by alternate or intermittent activity.

When present-day landforms have been modelled by processes no longer active or when they are exhumed after long periods of time and are successively re-exposed (fossil landforms; Bisci, Dramis, 1991), they are considered as relict. However, Bisci and Dramis, (1991) do not considered these landforms necessarily inactive. Instead, according to the Authors, inactive landforms are those that do not evolve under the action of the processes in which they are generated, but they can still be modified over time by different processes. Moreover, a landform might have been generated in a past morphoclimatic system or under tectonic and structural conditions that are no longer active, or it may be currently evolving and changing in shape, features and size under the action of processes that are different from the genetic ones.

Castaldini et al. (2009) classified landforms activity with reference to the period of the field survey: landforms were considered active when active processes were observed during the period of field work, whilst inactive landforms were those which were not affected by tangible processes occurring during the same period.

In all of these definitions, time is the key word in distinguishing the landform origin. In fact, the persistency of the landforms, i.e., the period from formation to dismantling via stages of degradation, depends inversely on the temporal duration of their genetic processes and directly on their own spatial scale.

The glacial environment is a typical example of climate-depending modification of landforms and of the distinction between genetic and cur-

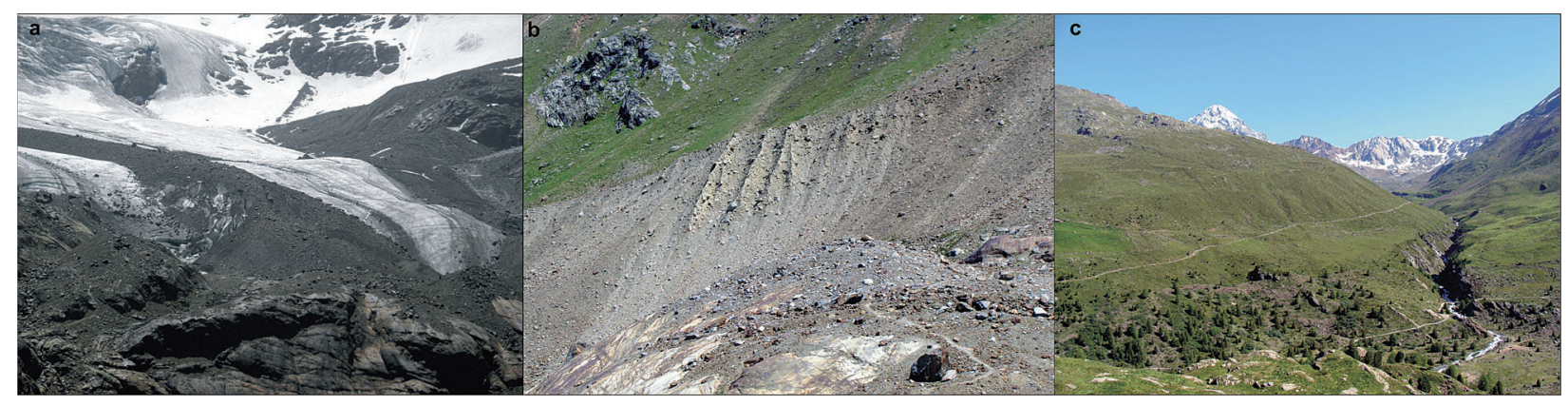

Fig. 1. Examples of moraines and activity of processes in the Forni Valley (Valtellina, Italy). a) Medial moraine of the Forni Glacier. It can be considered an active geomorphosites whose evolution is still determined by glacial processes; b) upper portion of the lateral moraine of the Forni Glacier, dating back to the Little Ice Age peak. The lateral moraine is, at present, affected by running waters, responsible for the formation of gullies, and by gravity processes, causing the fall of blocks (passive geomorphosites affected by geomorphological processes different from the genetic ones); c) moraines dating back to the Late Glacial Maximum, on the right side of the Cedec Valley, a tributary valley of the Forni Valley: they may be considered a passive geomorphosite and a relatively inactive landform (see Bisci \& Dramis, 1991), belonging to a past morphoclimatic system and currently not rapidly evolving (photo by I. Bollati: 2011; 2013) 
rent processes acting on landforms. The glaciers shrinkage leads to the modification of the glaciers typology as well as of the morphology of deglaciated areas with the continuous enlargement of the proglacial areas (Garavaglia et al. 2010). Moraines witnessed the past position of the glacier front, but they can still face deep modifications deriving by the reworking of the glacial deposits by running water or by ice core melting (Curry et al. 2009, Smiraglia et al. 2009). Ancient lateral and frontal moraine ridges are inactive with respect to current glacial processes, following the classification of Bisci and Dramis (1991), but, especially in high mountain environments, they may be considered under the influence of active processes such as running water and gravity or, in more general, mass wasting processes that are different from the genetic ones. Medial moraines, on the contrary, are still actively being shaped by differential ablation processes (Smiraglia 1989) (Fig. 1a, b).

\section{Geomorphosite definitions according to processes activity}

According to Reynard (2004 b), a geomorphological landscape is a portion of the geomorphological context that is viewed, perceived, (and sometimes exploited) by Man and, when perceived by humans and characterised by certain attributes, it may be considered a wider geomorphosite (Reynard, Panizza 2005) or a complex of geomorphosites inside of which single geomorphosites can be individuated. Moreover, single geomorphosites belong to a landscape system that is dynamic, and thus the comprehension of a geomorphosite mechanism requires good observations, measurements and quantifications of processes (Reynard 2004b).

To indicate sites of geomorphological interest that best express the dynamicity of landscape systems, several terms have been proposed in the literature. Hooke (1994) introduced the general concept of dynamic geomorphological sites, which was later widened by Strasser et al. (1995), who proposed the distinction between static and active geotopes, and Reynard (2004b; 2005), who suggested the use of active or dynamic geosites (as well as Bini 2009, Koster 2009). Marty et al. (2004), referring to Serbia's geoheritage, considered the active processes among the immovable (in situ) geoheritage.

After 2004, the most commonly used terms are active geosite or geotope and the contrasting passive geosite (Reynard 2004a, 2005, Ilies, Josan 2007, Reynard et al. 2007, Gavrilâ, Anghel 2013, Warowna 2013). Since this distinction has been mainly applied to the sites of geomorphological interest, the new terms active geomorphosites (AGs) and passive geomorphosites (PGs) have been coined, in which the strictly geological features are considered as attributes in assessing the site scientific value (i.e. other geological interests; Bollati et al. 2012a).

Reynard (2004a) defined AGs as those that "allow the visualization of geo(morpho)logical processes in action" (e.g., river systems, proglacial areas, active volcanoes, badlands) and are ideal situations in which quantify this action (Ilies, Josan 2007), as well as the climate variations influencing the processes intensification (Reynard 2004 b). Zouros (2010), discussing AGs, emphasizes tectonic controlled landforms, as they are often forgotten because of the greater attention paid to morphoclimatic systems changes.

In addition, it is easy to find a correlation between $A G s$ and the active landforms as defined by Castaldini et al. (2009), i.e., sites in which the visualisation of processes should be possible in the time interval of the permanence on the field.

According to Slaymaker et al. (2011) AGs correspond to geomorphological hotspots, independently from the spatial scale (sites or landscapes) that have a great value in term of geodiversity and that are highly vulnerable to environmental change.

In general, $A G s$ may be considered of great interest for three reasons:

1. geomorphological processes might cause irreversible modifications and threaten the survival of sites vulnerable to environmental changes (Hooke 1994, Bini 2009, Koster 2009, Slaymaker et al., 2011, Bollati et al. 2012b);

2. these sites witness the dynamicity of the processes of the Earth's surface and the ongoing landscape evolution, which may have educational value (Reynard 2004a, b, Bini 2009, Bollati et al. 2011, i.e. educational exemplarity, Bollati et al. 2012a, Gavrilâ, Anghel 2013); and 
3. active processes may be responsible for hazards and risks related to their fruition (Brandolini et al. 2006, Pelfini et al. 2009, Reynard 2009, Bollati et al. 2013).

In 1994, Hooke was the first to emphasize how AGs allow for the observation of processes and how they have scenic and ecological importance (see also Reynard 2004 b, Bini 2009, Kostner 2009). As noted by Reynard et al. (2007), A geomorphosite with a high educational value may be a place where the landforms are particularly visible in the landscape or where the processes are particularly active (i.e., educational exemplarity; Bollati et al. 2012 a). Moreover, the roles of active processes are considered meaningful for those with interest in geodiversity. The attribute of geodiversity is used within the evaluation procedures and may be intended strictly in a geomorphological sense, as Eberhard (1997) does: a range of processes (biological, hydrological and atmospheric) currently acting on rocks, landforms and soils or in a broader sense, as proposed by Gray (2004): the natural range (diversity) of geological (rocks, minerals, fossils), geomorphological (land form, physical processes) and soil features. It includes their assemblages, relationships, properties, interpretations and systems. In both cases, geodiversity represents the ground for the development and differentiation of the biotic component of the environment (biodiversity) (Hooke 1994, Stanley 2000, Gray 2004, Koster 2009, Smith et al. 2009, Dusar, Dreesen 2012, i.e., ecologic support role, Bollati et al. 2012a).

PGs and AGs are worthy of attention for their scientific value because geosites are valuable for the study of the history of Earth Science, with particular attention to both past (i.e. paleoenvironment conditions, Reynard 2005; model of paleogeomorphological evolution; Bollati et al. 2012 a) and present geomorphological conditions.

In general, landscapes present a combination of inherited (Bosson, Reynard 2011; i.e., passive geosites for Reynard 2004 a) and active landforms (Bosson, Reynard 2011; i.e. active geosites for Reynard 2004 a) that are worthy to be considered geomorphosites. As for landforms, the temporal persistence of morphological processes has to be considered. Processes may have been active over a long duration, with differences in intensity, frequency and areal distribution due to changes in geodynamic and climatic conditions acting on different lithological types (Piacentini et al. 2011).

Even if the definitions of active and inactive landforms and active and passive geomorphosites are clear and consistent, as mentioned before, there is sometimes confusion regarding the relationship between the current processes acting on the geomorphosite and the processes responsible for the genesis of the geomorphosite.

According to the above definitions in the literature on AGs, the landforms that may be included, when characterised by opportune attributes, are only the strictly active ones, while among the PGs, the quiescent (border-line sites depending on the return time), inactive, fossil (or relict) landforms may be considered.

Nevertheless, in the framework of geoconservation, promotion, impact and risk mitigation, active processes are very important and they can act on both AGs and PGs. In fact, not only can geomorphosites be continuously modified by the same processes that have created them, as in the case, for example, of the calanchi landscape (Bollati et al. 2012b), but in changing morphoclimatic systems, they may undergo modifications due to processes that are different from the genetic ones and that are responsible for the current evolution of landforms, as in the case of reworked glacial deposits and depositional landforms in general (or inactive landforms) (see Bisci, Dramis 1991). For example, a lateral moraine that is continuously reworked by running water has to be considered a $P G$ because it is not modified at present by glacial processes and is thus an inactive that currently evolves under the action of other processes (Fig. 1b).

\section{Geomorphosite change implications}

There are many potential implications that justify the attention towards $A G s$ in the strict sense and inherited landforms (Bosson, Reynard 2011) especially when they are considered geomorphosites affected by undergoing change.

\section{Degradation}

AGs and PGs are both susceptible to modifications due to processes that change in time, fre- 
quency and intensity. For example, when morphoclimatic balance breaks down, the correlated landforms may change according to the new climatic conditions. In addition to the previous examples, periglacial landforms may be considered; for example, the melting of buried ice can change the shape and classification of typical alpine landforms (Diolaiuti, Smiraglia 2010), such as rock glaciers.

In most situations, the degradation of the sites can induce modifications in the attributes considered in the assessment and evaluation procedures. Representativeness, integrity, rarity, educational exemplarity and geohistorical importance can be threatened by the modifications occurring to the sites, either naturally or human induced.

Modifications in geomorphological processes also influence vegetation distribution and dynamics (i.e., ecological support role, Bollati et al. 2012a) as in proglacial areas, where the glacier retreat is followed by trees colonisation (i.e., ecesis; McCarthy, Luckman 1993, Garavaglia et al.
2010) or on the valley slope (e.g., treeline shift; see Caccianiga et al. 2008, Leonelli et al. 2009) (see detailed analysis in 3.2 paragraph). Moreover, when landforms previously buried by ice, come to light, they represent new elements that support and increase geodiversity (e.g., Diolaiuti, Smiraglia 2010, Garavaglia et al. 2010).

Many AGs and PGs have great cultural value (see Panizza, Piacente 2003), as they may be, for example, connected historical buildings or surrounded by a spectacular view, such as the old towns or abbeys in the calanchi areas of Italian Apennines (e.g.: Civita di Bagnoregio, "the dying town", Viterbo; Monte Oliveto Maggiore, Siena ). In these cases, the geomorphological processes responsible for the aesthetic attribute of the site are the same that threaten their survival (Bollati et al. $2012 b)$. In fact, if we examine landscapes originated by surface runoff, such as those characterising Italian Apennines, extreme rainfalls events can speed up the erosion rates of clay lithologies (Della Seta et al. 2009), causing the progressive

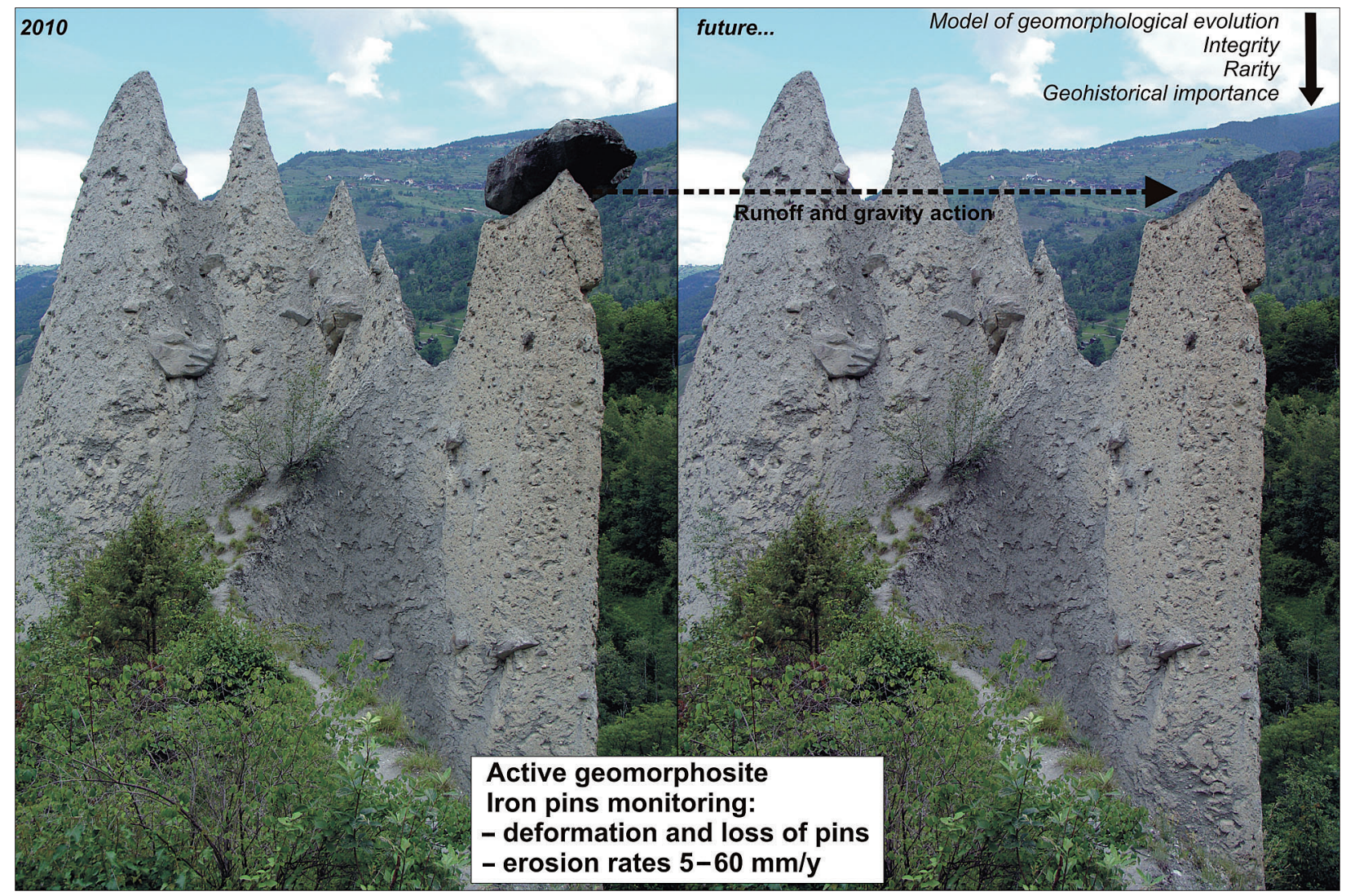

Fig. 2. The Pyramids d'Euseigne (Canton Valais, Switzerland) and the possible influence of their evolution, under runoff and gravity processes, on the attributes of the landform as geomorphosite. The reported erosion rate is referred to Table 1 (photo by I. Bollati, 2010, modified) 
dismantling of badlands (AGs). Some calanchi in Tuscany have been changing in typology since the 1970 's, from sharp and edge landforms to rounded landforms with diffuse gravity processes, as a consequence of changes in rainfall regimes and human intervention (Ciccacci et al. 2008).

Runoff action is responsible for other kinds of scenic landforms, such as earth pyramids, which are shaped by running water on the heterometric glacial deposits; in this case, the coarser blocks protect the finer sediments, leading to the formation of a pyramidal shape. These landforms may be shaped in un-modelled glacial deposit or into well defined moraines. In the last case moraines witness the past extension of glaciers (i.e., paleogeomorphological model see Bollati et al. 2012a) but are currently worked by running water (i.e., geomorphological model see Bollati et al. 2012a).

Earth pyramids can face modifications within a few years (Pellegrini et al. 2005) or require direct monitoring to detect slow evolution (Fig. 2). As an example, the Pyramids d'Euseigne (Canton Valais, Switzerland) represent an exemplary case of moraines currently reworked by running water and as $P G$ s undergoing change. Surface runoff and gravity may lead to a progressive disman- tling of earth pyramids and consequently to the loss of features characterizing the geomorphosite such as integrity, rarity and others (Fig. 2).

As previously indicated, $P G s$, that may be no longer linked to the morphoclimatic context in which they were generated, may undergo modifications that might be irreversible if they are involved in new types of processes that deeply modify their original and distinctive features (Lugon, Reynard 2003).

The degradation of both AGs and PGs as a consequence of the intensification of the active processes induced Rivas et al. (1997) to define these sites as consumable sites. An acceleration in surface processes increases the degree of susceptibility of geomorphosites (see Irasema Alcantara Ayala personal communication; Hooke 1994, Gavrilâ, Anghel 2013). This susceptibility requires attention from people concerned with sites conservation and management (Hooke 1994, Reynard 2004b, Bini 2009, Koster 2009, Thomas, 2012).

Geomorphological dynamic is also important for what concerns geoconservation that regards different environments where geological/ geomorphological processes can be observed and studied (Bini 2009, Smith et al. 2009, Koster

Table 1. Results of erosion rates on different kind of deposits under different climate conditions. The data have been collected both analysing references and review papers (e.g. Stoffel et al. 2013, Rovera, Delannoy 1996) and adding new field data (i.e. unpublished data)

\begin{tabular}{|c|c|c|c|c|c|c|}
\hline PROCESS & & $\begin{array}{l}\text { Min ER } \\
\left(\mathrm{mm} \mathrm{y}^{-1}\right)\end{array}$ & $\begin{array}{l}\text { Max ER } \\
\left(\mathrm{mm} \mathrm{y}^{-1}\right)\end{array}$ & $\begin{array}{l}\text { Average ER } \\
\left(\mathrm{mm} \mathrm{y}^{-1}\right)\end{array}$ & Method & Reference \\
\hline $\begin{array}{l}\text { Runoff on fine } \\
\text { deposits (e.g. }\end{array}$ & \multirow{3}{*}{$\begin{array}{l}\text { Warm } \\
\text { temperate }\end{array}$} & 0.59 & 20.1 & 10.35 & $\begin{array}{l}\text { Dendrogeomorphol- } \\
\text { ogy }\end{array}$ & $\begin{array}{l}\text { Reference in Stoffel } \\
\text { et al. } 2013\end{array}$ \\
\hline & & & & & & \\
\hline \multirow{2}{*}{$\begin{array}{l}\text { Runoff fine } \\
\text { deposits (e.g. } \\
\text { marine shales) }\end{array}$} & & 0.45 & 75 & 37.73 & $\begin{array}{l}\text { Topographic meas- } \\
\text { urements }\end{array}$ & $\begin{array}{l}\text { Reference in Delan- } \\
\text { noy, Rovera } 1996\end{array}$ \\
\hline & Arid & 0.07 & 8.25 & 4.16 & $\begin{array}{l}\text { Dendrogeomorphol- } \\
\text { ogy }\end{array}$ & $\begin{array}{l}\text { Reference in Stoffel } \\
\text { et al. } 2013\end{array}$ \\
\hline \multirow{4}{*}{$\begin{array}{l}\text { Runoff on } \\
\text { heterometric } \\
\text { deposits (e.g. } \\
\text { glacial deposit) }\end{array}$} & Polar & & & 300 & $\begin{array}{l}\text { Topographic meas- } \\
\text { urements }\end{array}$ & Smiraglia et al. 2009 \\
\hline & \multirow{3}{*}{ Subalpine } & 3.04 & 7.14 & 5.09 & $\begin{array}{l}\text { Dendrogeomorphol- } \\
\text { ogy }\end{array}$ & \multirow{2}{*}{ Unpublished data } \\
\hline & & 5 & 60 & 35.7 & $\begin{array}{l}\text { Topographic meas- } \\
\text { urements }\end{array}$ & \\
\hline & & & & 0.01 & $\begin{array}{l}\text { Topographic meas- } \\
\text { urements }\end{array}$ & $\begin{array}{l}\text { Reference in Delan- } \\
\text { noy, Rovera } 1996\end{array}$ \\
\hline
\end{tabular}


2009) and their potential degradation due both to natural processes and bad management practices (Reynard 2004a, Reynard, Panizza 2005, Bini 2009, Smith et al. 2009, 2011).

Hence, geomorphological dynamics may represent a problem for geoheritage protection (Bini 2009, May 2008). Thus, a deep knowledge of processes and their historical evolutions and of the relations between surface processes and the environment is required (Reynard 2004b, Smith et al. 2009) as well as the reconstruction of past damaging geomorphological events (Smith et al. 2009, Bollati et al. 2012b, Guida et al. 2008).

An example of approach used to define the geomorphological hotsposts (see definitions above) and to monitor their evolution are the geoindicators (Berger, Iams 1996, Rivas et al. 1997) applied for measuring processes responsible of short term change (less than 100 years).

Landforms (e.g. those due to runoff intensity) and, consequently, corresponding geomorphosites evolution rates, may be different according to the type of deposits and climate conditions (some results are reported in Table 1). Rates can be measured through different methods based on biological (e.g., Stoffel et al. 2013) and abiological components of the environment (e.g. Delannoy, Rovera 1996), and the derived data may be considered the starting point for forecasting the rates of evolution or degradation of both active and passive sites of geomorphological interest (Smith et al. 2009, Bollati et al. 2012b).

\section{Ecological importance}

According to Hooke (1994), active processes create a range of ecological habitats and thereby maintain ecological diversity (Gray 2004, Smith et al. 2009); ecosystem health benefits from active geological processes (Dusar, Dreesen 2012).

Representative examples can be found in climatically limited areas, such as in the upper Alpine valley systems where global warming is inducing a shift in treelines (e.g., Caccianiga et al. 2008, Leonelli et al. 2009), an enlargement of the proglacial areas as a consequence of glacier retreat (Garavaglia et al. 2010) and an increasing supraglacial debris (e.g., Deline 2009). One of the most important transformations is that from debris-free glaciers to debris-covered glacier. When the debris coverage is located below the treeline, its thickness and grain size are proper, and when the glacier surface velocity is low, the debris can be colonised by trees (Benn, Evans 2010, Leonelli, Pelfini 2013). On the Italian Alps, the most representative debris-covered glacier is the Miage Glacier in the Mount Blanc Massif; it has also been described as a geomorphosite, specifically a complex geomorphosite (Bollati et al. 2013). Supraglacial trees growing on its debris coverage represent accurate archive of climatic and glaciological data used to reconstruct the recent complex movements of the glacier surface, to detect the more unstable portion of the glacier tongue, characterised by two main lobes, and to also analyse the trees distribution in relation with different surface velocities and debris features (Leonelli, Pelfini 2013). According to these most recent findings, the changes to the global value of complex geomorphosites has been evaluated in relation to the growing importance of the ecological support role; in a specific case, the Miage Glacier is strictly linked with past and present active processes. The increasing importance of the ecological support role may influence other attributes of the scientific value, such as rarity, model of geomorphological and paleogeomorphological evolution, as well as the geohistorical importance of sites, which would also increase, as a consequence, the global value of the geomorphosites.

\section{Educational activities and geotourism}

Active processes are of great interest for educational applications because annual changes occur on a human time scale, thus facilitating the perception of dynamicity of the environment by common people (Hooke 1994, Reynard 2004b, Bollati et al. 2011, i.e., educational exemplarity, Bollati et al. 2012a). The different scales of active processes, especially in the case of PGs, allow people to get in touch with different spatial and temporal concepts. The result of accelerated dynamics is reflected in annual changes in landforms, which may represent an element of attractiveness from both educational and scientific viewpoints (Gavrilâ, Anghel 2013). Fieldwork and laboratory experiments may be proposed for studying the activity of processes (e.g., Pelfini et al. 2010, Bollati et al. 2011) and adapting related educational 
materials for different target audiences (Pralong 2005). In this sense, the methods used for and the results deriving from direct monitoring of changing geomorphosites in which processes are active (see Table 1) may be considered a topic for dissemination (Bollati et al. 2011).

\section{Hazard and risk}

AGs, PGs and processes currently acting on both these categories are fundamental in the framework of geomorphological resources usable by society because of the possible onset of risk scenarios. Hazardous processes may affect human structures and touristic elements (Bell 1998, Brandolini et al. 2006, Piccazzo et al. 2007, Smith et al. 2009), especially in the cases of equipped naturalistic and geotouristic trails (Bollati et al. 2013). At this scope, proposals have been put forward for mapping hazards along touristic trails (e.g. Coratza et al. 2008, Pelfini et al. 2007 Piccazzo et al. 2007 and references herein) in order to disseminate concepts regarding the dynamicity of the natural environment and the correct practices for moving inside a dynamic environment (Smith et al. 2009, Bollati et al. 2013).

Moreover, many local studies have been carried out in order to detect the more frequently occurring hazards affecting touristic and cultural trails. For example, in the Italian mountain environment, the path network of the Lombardy sector of the Ortles Cevedale Group has been analysed (e.g., Piccazzo et al. 2007 and references herein), including the anthropic glaciers, such as Vedretta Piana Glacier, that are used for summer skiing (Diolaiuti et al. 2006). Similar studies have regarded different morphogenetic and morphoclimatic environments, such as in the Liguria coastal region where a landslide hazard has been studied in relation with sunbathing areas on beaches located under rock cliffs and along exposed trails (Brandolini et al. 2006).

These kinds of studies can be used to produce tourist maps that include scientific data as well as information about hazards (i.e., active processes) and landscape morphological features that potentially increase the vulnerability of users, such as the following: i) narrow trails crossing stable but steep slopes; ii) trails which pavement characteristics can change in relation with meteoro- logical conditions (e.g. rocky bedrock slippery under raining conditions); and iii) exposed trails, i.e., trails easy to walk but facing hanging rock walls. Pelfini et al. (2007) proposed legend symbols for geotouristic maps that are useful and are easy to identify trail characteristics that could influence their practicability and, consequently, increase user vulnerability and modify risk scenarios.

\section{Discussion and conclusions}

Geomorphosites affected by active processes are of great importance under several points of view: valorisation, conservation, risk and impact related to natural process and tourism. Active landforms, and consequently active geomorphosites, allow an individual to observe and understand the dynamicity of the present reliefs as well as allow for the comprehension of the present geomorphological processes shaping the Earth's surface (Reynard 2004a). Inactive landforms, and thus passive geomorphosites, are archives of information about the past environment (Reynard 2005). Moreover, passive geomorphosites are relevant when also affected by active processes even if different from their originating processes, as they encounter the same problems as active geomorphosites.

Considering the above points, we propose for the passive geomorphosites that are rapidly changing under the current dynamic conditions, the specific term evolving passive geomorphosites (ePGs) (Fig. 3).

The introduction of the term $e P G s$ does not modify the existing and generally accepted definitions, but allows underlining more explicitly the different meaning of geomorphic activity, giving a qualifying attributes to the inherited landforms (see Bosson, Reynard 2011).

In this sense active and evolving passive geomorphosites have also an educational value because they allow to: i) link active processes and geomorphological hazard concepts, ii) understand the role of hazardous processes in landscape evolution, iii) put in relation landforms evolution with geodiversity changes and iv) get in touch with concepts of different spatial and temporal dimensions. 


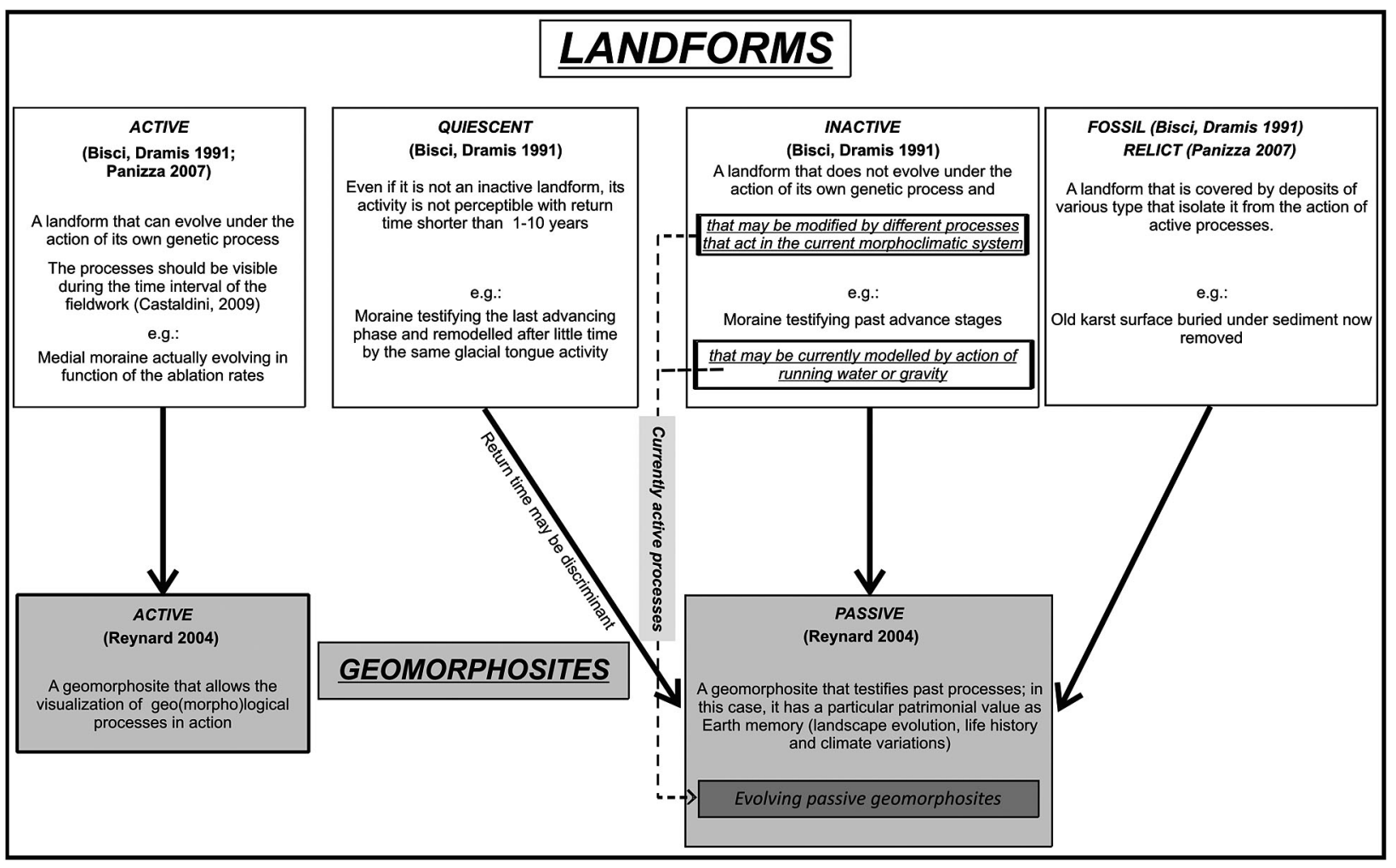

Fig. 3. The relation between landforms and geomorphosites definitions according to the processes activity. The new proposed category of evolving passive geomorphosites is indicated

The reconstruction of past geomorphological events and the evaluation of the current evolution rates (e.g., erosion rate) allow one to estimate their influence on geomorphosite integrity and to predict future evolution of the site itself (e.g., Smith et al. 2009, Bollati et al. 2012b). Such activities are particularly important when sites are related with cultural assets in the strict sense or when inserted in tourist contexts.

The discussion and the examples reported in this paper produce the following considerations: 1. the scientific literature involves detailed discussion about definitions of active and inactive landforms and active and passive geomorphosites that are mostly consistent;

2. the most recent research on geomorphosites gives importance not only to active geomorphosites (see Reynard 2004a) but also to passive geomorphosites characterized by ongoing changes (ePGs);

3. extreme landscapes, most sensible to climate change (geomorphological hotsposts sensu Slaymaker et al. 2011), are particularly interesting in the education and cultural frames due to the presence of both active and evolving passive geomorphosites;
4. the monitoring and quantification of processes involving geomorphosites, using the most suitable techniques and according to the different categories of sites and the different morphoclimatic systems, are fundamental to successful management practices.

Concluding, the constantly growing interest in changing landforms under changing climate conditions requires a twofold approach: on one side it is important to improve the value of the cultural proposals, on the other side discussions on geomorphosites need to imply an approach towards both scientific analysis and Earth sciences dissemination.

\section{Acknowledgements}

The research was performed in the framework of the PRIN 2010-2011 project (grant number 2010AYKTAB_006) Response of morphoclimatic system dynamics to global changes and related geomorphological hazards (local leader C. Smiraglia and national leader C. Baroni), founded by MIUR (MINISTERO DELL'ISTRUZIONE, DELL'UNIVERSITÀ E DELLA RICERCA). The Authors 
are grateful to Prof. E. Reynard for collaboration during the analysis of data regarding the geomorphosite of the Pyramids d'Euseigne and to Proff. A. Carton and C. Smiraglia for scientific discussion.

\section{References}

Bell F.J., 1998. Environmental geology. Principles and Practice. Blackwell Scientific Publisher, Oxford.

Benn D.I., Evans D.J.A., 2010. Glaciers and glaciations. $2^{\text {nd }}$ edition.s Hodder Arnold Publication, London.

Berger A.R., Iams W.J., 1996. Geoindicators: Assessing Rapid Environmental Changes in Earth Systems. A.A. Balkema, Rotterdam.

Bini M., 2009. Geomorphosites and the conservation of landforms in evolution. In: P. Coratza, M. Panizza (eds), Geomorphology and Cultural Heritage, Memorie descrittive della Carta Geologica d'Italia 87/2009: 7-14.

Bisci C., Dramis F., 1991. Il concetto di attività in geomorfologia. Geografia Fisica e Dinamica Quaternaria 14(2): 193-199.

Bloom A.L., 1991. Geomorphology: a systematic analysis of late Cenozoic landforms. Prentice Hall, Upper Saddle River, NJ.

Bollati I., Pelfini M., Pellegrini L., Bazzi A., Duci G., 2011. Active geomorphosite and educational application: a didactical itinerary along Trebbia River (Northern Apennines, Italy). In: E. Reynard, L. Laigre, N. Kramar (eds), Les géosciences au service de la société. Actes du colloque en l'honneur du Professeur Michel Marthaler. Institut de géographie, Géovisions, Lausanne 37: 219-234.

Bollati I., Pelfini M., Pellegrini L., 2012a. A geomorphosites selection method for educational purposes: a case study in Trebbia Valley (Emilia Romagna, Italy). Geografia Fisica e Dinamica Quaternaria 35(1): 23-35.

Bollati I., Della Seta M., Pelfini M., Del Monte M., Fredi P., Lupia Palmieri E., 2012 b. Dendrochronological and geomorphological investigations to assess water erosion and mass wasting processes in the Apennines of Southern Tuscany (Italy). Catena 90: 1-17.

Bollati I., Smiraglia C., Pelfini M., 2013. Assessment and selection of geomorphosites and trails in the Miage Glacier Area (Western Italian Alps). Environmental Management 51: 951-967.

Bosson J.B., Reynard E., 2011. Geomorphological heritage, conservation and promotion in high-alpine protected areas. Journal on Protected Mountain Areas Research, 4/1, 12/2011: 13-22, DOI:10.1553/eco.mont-4-1s13.

Brandolini P., Faccini F., Piccazzo M., 2006. Geomorphological hazard and tourist vulnerability along Portofino Park trails (Italy). Natural Hazards and Earth System Sciences 6: 1-8.

Brierley G., Fryirs K., Cullum C., Tadaki M., Huang H.Q., Blue B., 2013. Reading the landscape Integrating the theory and practice of geomorphology to develop placebased understandings of river systems. Progress in Physical Geography 37(5): 601-621.

Caccianiga M., Andreis C., Armiraglio S., Leonelli G., Pelfini M., Sala D., 2008. Climate continentality and treeline species distribution in the Alps. Plant Biosystems 142(1): 66-78.

Castaldini D., Valdati J., Ilies D.C., 2009. Geomorphological and Geotourist Maps of the Upper Tagliole Valley
(Modena Apennines, Northern Italy). In: P. Coratza, M. Panizza (eds), Geomorphology and Cultural Heritage - Geomorfologia e beni culturali, Memorie descrittive della Carta Geologica d'Italia 87/2009, pp. 29-38.

Ciccacci S., Galiano M., Roma M.A., Salvatore M.C., 2008. Morphological analysis and erosion rate evaluation in badlands of Radicofani area (Southern Tuscany - Italy). Catena 74(2): 87-97.

Coratza P., Ghinoi A., Piacentini D. Valdati J., 2008. Management of geomorphosites in high tourist vocation area: an example of Geo-Hiking maps in the Alpe di Fanes (Natural Park of Fanes-Senes-Braies, Italian Dolomites). Geojournal of Tourism and Geosites 2: 106-117.

Curry A.M., Sands T.B., Porter P.R., 2009. Geotechnical controls on a steep lateral moraine undergoing paraglacial slope adjustment. Geological Society, London, Special Publications 320(1): 181-197.

Della Seta M., Del Monte M., Fredi P., Lupia Palmieri E., 2009. Space-time variability of denudation rates at the catchment and hillslope scales on the Tyrrhenian side of Central Italy. Geomorphology, 107(3): 161-177.

Delannoy J.J., Rovera G., 1996. Conclusion: L'érosion dans les Alpes occidentales: contribution à un bilan des mesures et des methods (Erosion in the western Alps: a contribution to an assessment of measurements and methods). Revue de géographie alpine 84(2): 87-101.

Deline P., 2009. Interactions between rock avalanches and glaciers in the Mont Blanc Massif during the late Holocene. Quaternary Science Reviews 28: 1070-1083.

Diolaiuti G., Smiraglia C., Pelfini M., Belò M., Pavan M., Vassena G., 2006. The recent evolution of an Alpine glacier used for summer skiing (Vedretta Piana, Stelvio Pass, Italy). Cold Regions Science and Technologies 44 (3): 206-216.

Diolaiuti G., Smiraglia C., 2010. Changing glaciers in a changing climate: how vanishing geomorphosites have been driving deep changes in mountain landscapes and environments Géomorphologie: relief, processus, environnement 2: 131-152.

Dusar M., Dreesen R., 2012. Challenges to geoheritage conservation and sustainable development in Belgium. European Geologist 34: 8-11.

Eberhard R., 1997. Pattern and Process: Towards a Regional Approach to National Estate Assessment of Geodiversity. Technical Series No. 2, Australian Heritage Commission and Environment Forest Taskforce, Australia, Canberra.

Garavaglia V., Pelfini M., Bollati I., 2010. Influence of climate change on geodiversity in the alpine environment: the case of two Italian glacier investigated through dendrochronology. Géomorphologie: relief, processus, environnement 2: 153-164.

Garavaglia V., Pelfini M., 2011. Glacial geomorphosites and related landforms: a proposal for a dendrogeomorphological approach and educational trails. Geoheritage 3: $15-25$.

Gavrilă I.G., Anghel T., 2013. Geomorphosites inventory in the Măcin Mountains (South-Eastern Romania). GeoJournal of Tourism and Geosites 11(1): 42-53.

Giardino M, Perotti L., Carletti R., Russo S., 2010. Creation and test of a mobile GIS application to support field data collection and mapping activities on geomorphosites. In: G. Regolini-Bissig, E. Reynard (eds), Mapping Geoheritage. Institut de géographie, Géovisions, Lausanne 35, pp. $115-127$.

Grandgirard V., 1999. L'evaluation des Geotopes. Geologia Insubrica 4: 59-66. 
Gray M., 2004. Geodiversity: valuing and conserving abiotic nature. John Wiley and Sons Ltd, Chichester.

Guida D., Pelfini M., Santilli M., 2008. Geomorphological and dendrochronological analyses of a complex landslide in the Southern Apennines. Geografiska Annaler Series A Physical Geography 90(3): 211-226.

Hooke I.M., 1994. Strategies for conserving and sustaining dynamic geomorphological sites. In: D. O'Halloran, C. Green, M. Harley, M. Stanley, J. Knill (eds), Geological and landscape conservation, Geological Society of London Special Publications, pp. 191-195.

Ilieş D.C., Josan N., 2007. Preliminary contribution to the investigation of the geosites from Apuseni Mountains, Romania. Revista de Geomorfologie 9: 53-61.

Ilieş D.C., Josan N., 2008. Some theoretical aspects regarding the genesis of geosites. GeoJournal of Tourism and Geosite 1: 7-12.

Koster E.A., 2009. The "European aeolian sand belt: geoconservation of drift sand landscapes". Geoheritage, 1: 93-110.

Leonelli G., Pelfini M., Morra Di Cella U., 2009. Detecting climatic treelines in the Italian Alps: the influence of geomorphological factors and human impacts. Physical Geography, 30(4): 338-352.

Leonelli G., Pelfini M., 2013. Past surface instability of Miage debris-covered glacier tongue (Mont Blanc Massif, Italy): a decadal scale tree-ring based reconstruction. Boreas, DOI: 10.1111/j.1502-3885.2012.00291.x.

Lugon R., Reynard E., 2003. Pour un inventaire des geotopes du canton du Valais. Bullètin Murithienne 121: 83-97.

Marty D., Cavin L., Hug W., Jordan P., Lockley M.G., Meyer C., 2004. The protection, conservation and sustainable use of the Courtedoux dinosaur tracksite, Canton Jura, Switzerland. Revue de Paléobiologie 9, (2004): 39-49.

May V.J., 2008. Integrating the geomorphological environment, cultural heritage, tourism and coastal hazards in practice. Geografia Fisica e Dinamica Quaternaria 31(2): 187-194.

Mccarthy D.P., Luckman B.H., 1993. Estimating ecesis for tree-ring dating of moraines: a comparative study from the Canadian Cordillera. Arctic Antarctic and Alpine Research 25: 63-68.

Panizza M., 2001. Geomorphosites: concepts, methods and examples of geomorphological survey. Chinese Science Bulletin, 46: 4-6.

Panizza M., Piacente S., 2003. Geomorfologia culturale. Pitagora Editrice, Bologna.

Pelfini M., Brandolini P., Carton A., Piccazzo M., 2007. Rappresentazione in carta delle caratteristiche dei sentieri ai fini della mitigazione del rischio geomorfologico (Cartographic representation of the trails characteristics for mitigation of geomorphological risk). Bollettino della Associazione Italiana di Cartografia 126-128: 101-123.

Pelfini M., Brandolini P., Carton A., Piccazzo M., 2009. Geo-tourist and geomorphological risk/impact. In: E. Reynard, P. Coratza, G. Regolini-Bissig (eds), Geomorphosites. Assessment, mapping and management. Pfeil Verlag, München, pp. 131- 143.

Pelfini M., Garavaglia V., Bollati I., 2010. Dendrogeomorphological investigations for assessing ecological and educational value of glacial geomorphosites. Two examples from the Italian Alps. In: G. Regolini-Bissig, E. Reynard (eds), Mapping Geoheritage. Institut de géographie, Géovisions, Lausanne 35, pp. 81-96.
Pellegrini L., Boni P., Vercesi P.L., Carton A., Laureti L., Zucca F., De Vita S., 2005. The Geomorphosites in Lombardy. Italian Journal of Quaternary Sciences 18: 39-62.

Piacentini T., Castaldini D., Coratza P., Farabollini P., Miccadei E., 2011. Geotourism: Some examples in Northern-Central Italy. GeoJournal of Tourism and Geosites 8: 240-262.

Piccazzo M., Brandolini P., Pelfini M. (eds), 2007. Clima e rischio geomorfologico in aree turistiche (Climate and geomorphological hazards in tourist areas). Pàtron Editore, Bologna.

Pralong J.P., 2005. A method for assessing tourist potential and use of geomorphological sites. Géomorphologie: relief, processus, environnement 3: 189-196.

Reynard E., 2004a. Geosites. In: A. Goudie (ed.), Encyclopedia of geomorphology, Routledge, London.

Reynard E., 2004b. Géotopes, géo(morpho)sites et paysages géomorphologiques. In: E. Reynard, J.P. Pralong (eds), Paysages géomorphologiques, Institut de géographie, Travaux et Recherches, Lausanne 27, pp. 124-136.

Reynard E., 2005. Geomorphosites et paysages. Géomorphologie: relief, processus, environnement 3: 181-188.

Reynard E., Panizza M., 2005. Geomorphosites: definition, assessment and mapping. An introduction. Géomorphologie: relief, processus, environnement 3: 177-180.

Reynard E., Fontana G., Kozlik L., Scapozza C., 2007. A method for assessing scientific and additional value of geomorphosites. Geographica Helvetica 62 (3): 148-158.

Reynard E., 2009. The assessment of geomorphosites. In: Reynard E., Coratza P., Regolini-Bissig G. (eds), Geomorphosites. Assessment, mapping and management. Pfeil Verlag, München, pp. 63-72.

Reynard E., Coratza P., 2013. Scientific research on geomorphosites. Geografia Fisica e Dinamica Quaternaria 36: 159168.

Rivas V., Rix K., Frances E., Cendrero A., Brunsden D., 1997. Geomorphological indicators for environmental impact assessment: consumable and non-consumable geomorphological resources. Geomorphology 18: 169-182.

Slaymaker O., Spencer T., Embleton-Hamann C., 2011. Geomorphology and Global Environmental Change. Cambridge University Press.

Smiraglia C., 1989. The medial moraines of Ghiacciaio dei Forni, Valtellina, Italy: morphology and sedimentology. Journal of Glaciololgy 35 (119): 81-84.

Smiraglia C., Belo M., D'agata C., Diolaiuti G., Mihalcea C., Pelfini M., 2009) The ice-cored moraine of Forni Glacier (Upper Valtellina) as an example of the transition from a glacial to a periglacial Alpine system. Memorie della Societa Geografica Italiana 87(2): 501-509.

Smith B.J., Orford J.D., Nicholas B.L., 2009. Management Challenges of a dynamic geomorphosite: climate change and the Giant's Causeway World Heritage Site. In: E. Reynard, P. Coratza, G. Regolini-Bissig (eds), Geomorphosites. Assessment, mapping and management. Pfeil Verlag, München, pp. 145-162.

Smith B.J., Ondicol R.P., Alexander G., 2011. Mapping slope instability at the Giant's Causeway and Causeway Coast World Heritage Site: implications for site management. Geoheritage 3(3): 253-266.

Stanley M., 2000. Geodiversity. Earth Heritage 14: 15-18.

Stoffel M., Corona C., Ballesteros-Cánovas J.A., Bodoque J.M., 2013. Dating and quantification of erosion processes based on exposed roots. Earth-Science Reviews 123: 18-34. 
Strasser A., Heitzmann P., Jordan P., Stapfer A., Stürm B., Vogel A., Weidmann M., 1995. Geotope und der Schutz erdwissenschaftlicher. Schweiz: ein Strategiebericht, Fribourg.

Summerfield M., 1991. Global Geomorphology. Prentice Hall, Upper Saddle River, NJ.

Thomas M., 2012. A geomorphological approach to geodiversity-its applications to geoconservation and geotourism. Quaestiones Geographicae 31(1): 81-89.
Tricart J., 1965. Principles et méthodes de la géomorphologie. Masson Ed., Paris.

Warowna J., Migoń P., Gawrysiak R.K., Kiebała A., Zgłobicki W., 2013. Geomorphosites of Poland-the role played by the Central Register of Geosites. Landform Analysis 22: $117-124$.

Zouros N., 2010. Lesvos Petrified Forest Geopark, Greece: geoconservation, geotourism, and local development. The George Wright Forum Journal 27: 19-28. 